\title{
Do not insult Papuans in front of me
}

Trajanus S. Boekorsjom

I would explode with anger when I saw Papuans receiving treatment that was unfit for human beings. In fact, I was almost fired as a civil servant by the governor of Netherlands New Guinea for opposing treatments I considered highly discriminatory.

One time, at the office of the hoofd plaatselijk bestuur (HPB, sub-division administrative head) ${ }^{1}$ of Hollandia-Haven (the area around the port of Jayapura), the Arso district head, Asser Demotokay, who was of Papuan descent, came to deliver a report on conditions in his district. When he entered the office he came before Pattiapon, the hoofd bestuurs-assistent (head assistant administrator) of Ambonese descent. Pattiapon's treatment was outrageous. He did not even invite Asser to sit down in the chair that was there. Asser was left to remain standing as he delivered his report orally.

As a Papuan, I just could not accept such treatment. At that time, the Ambonese really felt they were better than Papuans. They felt that after Dutch nationals, Ambonese were number two, with Papuans then forming a third, lower class beneath them. I entered Pattiapon's room and said, 'Mr. Pattiapon! Both you and we are all civil servants, working in this office only to carry out administrative coordination tasks. But the hierarchy in the government is held up by the governor, the resident, the HPB and the district head. Why, sir, have you not invited District Head Arso to sit in this chair? Is it because he is Papuan?' Holding the chair, I continued, 'Mr. Pattipon, this is your chair, now take this chair of yours.' I immediately hit him with that chair.

The incident was reported by the Dutch hoofdcommies (chief clerk) to the HPB. I was summoned, along with Pattiapon. Before the HPB, Mr.

\footnotetext{
1 In the 1950s, Netherlands New Guinea was administratively divided into six (6) divisions, 38 subdivisions, and 72 districts, led by residents (divisional commissioners), hoofd plaatselijk bestuur or HPBs (sub-division heads), and district heads, respectively.
} 
Pattiapon made his report. 'Trajanus, how is it that you went so far as to hit Mr. Pattiapon?' asked the HPB. 'Mr. HPB, to this day Mr. Pattiapon has failed to understand the organizational structure of the government. He is more ignorant than the Papuans, who are so often said to be ignorant. Mr. Pattiapon does not understand his function, the fact that we and Mr. Pattiapon are in this office only to coordinate the administration, but the ones who have leadership authority are the governor, resident, HPB, and district head. Maybe, to Mr. Pattiapon's way of thinking and feeling, the Arso district head, Mr. Asser Demotokay is merely a Papuan who need not be respected. He does not appreciate the district head as the direct subordinate or main servant of the HPB in the district. Because I did not approve or accept his manner, I hit him with the chair.'

After the HPB had listened to all our explanations, he advised Mr. Pattiapon that this way of humiliating and offending the feelings of Papuans had happened for the last time and must not be repeated again.

\section{BEST GRADUATE OF OSIBA}

The evening of Tuesday, 11 December 1951, was a tense moment for me and 16 friends who made up the first generation of the Opleidingsschool voor Inheemse Bestuursambtenaren (OSIBA, School for Indigenous Administrators). That night, after three years of study at OSIBA, we would hear the announcements of whether we had passed or not. We got ready, dressed neatly, and waited quietly in the study hall to attend the ceremony, as instructed by the Director of OSIBA, Mr. de Wilde.

The event would also be attended by those invited to watch the awarding of diplomas. The event was opened by Mr. de Wilde. The tension in the air became increasingly more palpable. But at last it turned into excitement, as all 17 of us were declared to have passed.

As we waited, suddenly my name was called out. My final exam scores were read aloud and I was declared the overall champion, the highest scorer. How delighted I was when the directeur culturele zaken (director of cultural affairs), Mr. de Jong, handed me the diploma I so desired. After that, I shook hands with Reverend Izak Samuel Kijne, and he immediately kissed me. Then my friends were called in turn to the front to receive their diplomas.

At that time I was informed by a representative of the directeur van 
binnenlands bestuur en justitie (chief director of internal administration and justice), that I would be rewarded with my choice of job after the decree regarding appointments was received. We were dismissed, and all of us went home to our own villages to wait for the decision on appointments and placements.

At the beginning of January 1952, the Decree of the Chief Director of the Department of Internal Administration and Justice Number 10, dated 9 January 1952, and signed by Assistant I t/b (seconded assistant I) Mr. Boendermaker, was issued. In the decree, the 17 of us were divided up as follows: seven of us were placed in the Noord Nieuw-Guinea (Northern New-Guinea) residency or division, two in the Zuid NieuwGuinea (Southern New-Guinea) residency, and eight in the West NieuwGuinea (Western New Guinea) residency. We were all appointed to the position of gediplomeerd candidaat bestuurs-assistent (qualified administrative assistant candidate). Based on the decree, I left Biak for my job posting in Hollandia (present-day Jayapura), and in Hollandia I began working as a civil servant.

I was placed for one year in office as an assistant directly below the HPB of Hollandia in Hollandia-Binnen (now Abepura). My first duty was to look after and maintain the cleanliness and beauty of HollandiaBinnen and Hollandia-Haven. The second duty was to serve as the griffier inheemse rechtspraak (clerk to the indigenous court) in Hollandia. All of the office facilities and houses in Hollandia were relics of the allied forces after the end of World War II. The job of overseeing the cleanliness and beauty of Hollandia city also included the supervision of the public cemetery in Hollandia-Binnen. Then I was posted in Tobati district as district head, and I stayed on as the indigenous court clerk since I was based in Hollandia-Binnen. After serving in Tobati, I returned to work at the HPB Hollandia office.

\section{ROLLING CORPSES}

In 1953, I was given the additional task by the Hollandia HPB to accompany Mr. Galis to conduct research on the culture and adat of the Papuan population on the coast of Numbay Bay (the bay east of Hollandia, then known as Humboldt Bay). There were only two kampung (villages) on the bay - Kayu Pulau and Kayu Batu. Mr. Galis had already prepared 
a study outline with a list of questionnaires to use to obtain data and information about Papuan life there.

The study was conducted day and night; each day from 7:30 to 14:00, and continuing at night from 19:00 to 2:00. By day we studied community life and asked people to collect ancient objects, also artistic products in the form of carvings, both from homes as well as boat bodies and boat prows, all with their original local names and uses. By night we sat together with the elder adat leaders, smoking and chewing betel while asking questions about community life.

The night-time meetings were aimed at letting the people give us information about the stars and clues about what should be done when certain stars appeared in the sky. It turned out that according to the people of Numbay Bay, stars, each with their own name, could serve as guides to when they should begin planting, what kinds of crops were suitable and unsuitable to plant, and when to go to sea, what kinds of fishes were abundant. There was even a star that people believed could warn of famine or other hazards.

In the village of Kayu Batu there seemed to be a unique tradition. When a death occurred, the corpse was brought to a red-earth mountain, where the corpse was rolled over and over on the red soil, and then placed inside a stone cave.

Based on the results of the research, Mr. Galis earned a doctorate in the Netherlands. I felt sorry because after his book, entitled, Papua's van de Humboldt-baai (Papuans of Humboldt Bay) was published, Mr. Galis no longer remembered me. He never sent me a book. But now some of my friends have the book here.

\section{TEARING UP A WARRANT}

Because I was still on duty at the HPB Hollandia office, I served as chairman of the Inheemse Rechtspraak of Hollandia. The court consisted of the district head, acting as voorzitter (chairman), the controller, acting as raadsman (legal counsellor), and two members consisting of korano (village heads). The Inheemse Rechtspraak applied to Papuan people, while Indonesian and European people were covered by the judiciary. The indigenous court had the duty and authority to prosecute cases of violations of the law, such as theft, embezzlement, assault or persecution, 
and murder committed by Papuans. A case could be tried once the proces verbaal (warrant) was executed and then sent to the indigenous court through the HPB.

After the warrant was studied and investigated, the chairman set the trial day and date. For the hearings, two village heads, known as korano kampung in the Hollandia area, were invited to serve as members of the hearing. Usually, the members who attended were the korano of the village of Nafri, Elie Uyo, and of the village of Tobati, Petrus Hamadi. And if they were not around, they were replaced by the ondoafi (adat leader) of Tobati, Kaleb Hamadi, and the korano of the village of Enggros, Frans Sanji.

Why were the korano made to serve as members of the indigenous court? Because the laws of the penal code were not fully applicable to Papuans, who were underdeveloped and did not yet understand new laws other than the adat laws of the jungle. The chairman of the session read the contents of the warrant issued by the police. Then the chairman of the court stated that there were elements in the deeds of the convicted person that were criminal according to the penal code. In view of the penal code, the convict would be given an appropriate sentence according to the articles of the criminal laws, for instance, a sentence of imprisonment for this many days, this many months or this many years would be decided.

After pronouncing the verdict, the chairman asked the members of the session to deliver their appeal. What the punishment for the deeds being examined and tried would follow adat law. After hearing the severity of the punishment to which such a case would be subject, the raadsman then gave his view and advice on the case on trial. After further deliberation, the decision was announced by the chairman with a knock of the hammer. At that time, aside from the laws of the penal code, the Ordekeur Molukken and Rooiekeur of $1938^{2}$ were also in effect.

\footnotetext{
Cowan (1954:3) wrote: 'The resident had, following Clause 129.2 the authority to issue standing orders of police which could include penal provisions. A number of these orders are still in force, both those from the Resident of the Moluccas and from the Resident of New Guinea.' 'Of the orders from the Resident of the Moluccas I mention, for example, the so-called Ordekeur (Favasche Courant, 28 Sept. 1937, no. 77, extra-bijv. no. 53), and the Buiten-rooikeur (Favasche Courant, 22 Sept. 1936, no. 76, extrabijv. no. 47)' (Cowan 1954:3, note 2). In correspondence Pim (J.W.) Schoorl (Huizen, 21-7-2011) mentioned Cowan's manuscript and lent me (LV) his copy. He added: 'The Ordekeur Molukken was used to issue regulations to the villages concerning the tidiness of the courtyards, the fencing of the plots, and the maintenance of the roads [...]. I think that [Governor] Van Baal in a circular to the administrative heads mentioned the Ordekeur Molukken to provide a legal basis to the actions of the administrators in the villages concerning these matters.'
} 
I had an interesting and unforgettable experience when I was chairman of the indigenous court. One day I received a telephone call from the police, that there was someone who had been detained by the police for 20 days. If a decision was not quickly reached, it would be necessary to issue a new arrest warrant. According to the provisions of the law, the first 20 days were covered by afdak (temporary house arrest in a makeshift shelter consisting of a roof and poles, in the compound behind the police barracks), but when it went past 20 days, a preventive arrest warrant was necessary. I then called the clerk and ordered the warrant for police custody be immediately provided to be signed, and directly called the police to pick up the warrant, then bring the convict to jail, handing the warrant to the jail guard. Before the warrant was signed, it had to be reread to check its contents.

At the time, the person serving as the clerk was the Ambonese assistant administrator, D. Pattiapon. When he reread the warrant containing the identity of the convict, at the word 'Papuan' he started laughing together with some Ambonese who were present in the office. I felt offended, because they were laughing at the word 'Papuan', which I saw as an insult. I directly stood up, and, grabbing the verdict and tearing it up, I hit the clerk. Loudly and sternly I ordered him, 'You will now type a new warrant and have it signed, then telephone someone from the police to come pick it up and bring the convict to jail.' Indigenous court trials could be held once a month if a sufficient number of warrants had been submitted by the police.

\section{ALMOST FIRED}

In connection with my duty to maintain the cleanliness and beauty of the city, one day I went to patrol Hollandia-Binnen. On Jalan Sekolah (formerly Schoolweg), I saw two trucks of Sentani women transporting stones from Waena. The women not only lifted the stones, but lowered them down from the trucks and then carried them to a place where houses were being built. Upon seeing this, I went directly to the office of the HPB and protested it. But Controleur van Voskuylen argued with me, saying: 'Say, Trajanus, among you people in Papua isn't it the women who pound sago and go fishing, while the men just live to eat?' 
As a human being with self-esteem, I got angry with Controleur van Voskuylen right away. I said to him, 'Is this the way a gentleman from the Netherlands comes to work in Papua? If you are unhappy with Papuans, please go back home to the Netherlands. Sir, as a civil servant who has come to develop and protect the people, why do you have an attitude like that?' The quarrel that ensued became physical. Because the head of the office reported it to Resident Lamers, I, together with Mr. van Voskuylen, came before the resident to contest our respective truths. After the resident resolved my issue with Van Voskuylen, he directly reported it to the Internal Administration and Justice Service, and Van Voskuylen finally received a penalty transfer to Kaimana to open up Kaimana as an onderafdeling (administrative sub division). So, Van Voskuylen became the first onderafdelingschef (or HPB, sub-division head) of Kaimana.

Because a great deal of attention was paid by His Excellency the governor to subordinate officials who were Papuans, employee housing was built for them in Hamadi. But all the newly built houses were very depressing. Cement mixtures were only used for the bottom parts of the walls. For ventilation at the top, wood was not used, but instead, only barbed wire. I immediately sent a letter to the government, because the Papuan people were being equated with animals to the point of using cages. I considered it a form of racial discrimination based on skin colour.

Since those who had planned and built the houses were from the Dienst van Openbare Werken (Department of Public Works), they were not happy, and subsequently lodged a protest to the governor. As a consequence, I was to be fired from the civil service. One afternoon at 16:00 two Papuan church leaders, namely, Reverends Izak Samuel Kijne and Dr. Kamma, suddenly arrived at my home. Reverend Dr. Kamma said: 'This morning, when Izak met with the governor, he saw in the government secretariat the minutes of the decree on your dismissal. This is why both of us have come, to propose that if you're fired, we'll arrange for you and Madame to depart for Oegstgeest in the Netherlands to study church administration. If you and Madame agree to our idea, the day after tomorrow at noon, we will bring you to Sentani airport so that at 13:00 that afternoon you and Madame can leave directly for the Netherlands.' My wife and I accepted their proposal and agreed to go to the Netherlands. 
I waited for my discharge. But the next morning Markus Kaisiepo called and informed me that the dismissal had been overturned, as Markus Kaisiepo had come before the governor and recommended I not be fired, so the kind plans of the two Papuan church leaders got cancelled in the end. Aside from the fact that I was still young, I felt that all of that was very encouraging and increased my enthusiasm to serve the community as a civil servant. I saw the plan for my dismissal as a trial I had to face. And more than that, it would make me more sensitive and diligent; motivate me to work faithfully, increasingly adding to my experience the longer I worked.

In addition to my main duties, the HPB gave me the additional task to work together with the Headmaster of the Catholic Primaire Middelbare School (PMS, Junior High School) in Hollandia-Binnen to conduct social research for three months on the lives of the residents of the city of Hollandia, especially the Papuan community. Every day, we went in and out of the homes of Papuan people, Indonesian people, and Dutch people. We started with research on the Papuan families. Through this study, the government wanted to get information about the people's daily lives. We asked the families we visited: Did they eat breakfast, lunch, and dinner every day? Did they wash clothes and use washing soap every day, and how many bars of bath soap got used up in a month's time? The answers and information that we obtained through the families was that each day they ate, but only lunch and dinner. Regarding the washing soap, each day they washed clothes and used the leftover washing soap for bathing, because they did not have enough money to buy bath soap.

Such was our task, and after that, we went into the Indonesian homes with the same questions. And for comparison, with no exception, we went into the homes of the Dutch families with the same questions. Also, we went to visit the centre for coolies (that was the name used for the Hollandia harbour workers) in Sentani. There, we saw their kitchens, and how surprised we were because the kitchen floors in the barracks appeared to be full of water puddles. We asked the cook: 'You cook here, but at meal time, where does everybody eat?' The answer we received was, 'We cook here and people eat here too, in the place where you men are standing right now.'

After three months we completed the research, and had to report on it to the government. Privately, I sent a letter to the governor and pleaded for a government policy to improve houses and cooking places, including 
cooking places for the coolies, who numbered hundreds of people. After the governor received my letter, I was directly summoned to appear before him. When I came before him, he answered my letter orally, saying that funds would be provided to build housing for the coolies, along with kitchens for cooking and eating. Then the governor ordered an arbeiderskamp (workers' camp) to be built in Dok II.

My experience kept growing. Not long after that, a new problem came up for me. In Kota Raja Dalam, the Protestants had established a PMS (junior high school) and a Lagere Technische School (LTS, Lower Technical School). When the LTS successfully graduated its first class, the young people did not know where to go, and they were unemployed. In light of this situation, I personally sent a letter to the governor questioning the fates of the first class of graduates of the Protestantmanaged LTS. Why not give them the opportunity to work? Finally, in answer to my letter, the LTS graduates were divided up, half of them accepted by the Rijkswaterstaat Dienst (Irrigation Department), and the other half distributed to companies such as Intervam, Hollandse Beton Maatschappij and Amsterdamse Ballast Maatschappij.

While working as a civil servant, I had plans to improve the quality of my education. One day I came before the DBBJ to ask for permission to follow studies at a higher educational institution. The adjunct administrative officer at Dok V said: 'You would not be capable of following studies there.' Right away I said to him: 'If that is the case, let us pull the school out and send it back to the Netherlands, so it will be for Europeans alone, but not here.' I also told the officer about when those of us from OSIBA who attended police studies at Base G for 13 months together with Indo-Dutch people; each time we went through testing, I was always the very first to hand in my paper to the examiner's desk, even though all courses were in the Dutch language.

\section{STRIKING THE DISTRICT HEAD}

In September 1955 I was transferred from the HPB Hollandia office to Sentani district with the aim of assisting the Sentani district head, and later taking his place. From the time I began in Sentani, it was obvious that the old district head was unhappy and did not agree to be replaced. Each day he showed his displeasure to me. But I did was not bothered 
by his attitude because I was not working for him, but for the people of West Papua.

One day, some people in Sentani were arrested for catching fish that had been released by the Fisheries Department. Fish hatchlings had been released in Lake Sentani in 1953 with the goal that when they grew big and multiplied, they could be consumed by the local community and residents of Hollandia city. The Sentani people were arrested because it was not the time yet to catch the fish. The Sentani people who were arrested were given the penalty of herendienst (compulsory labour) by the Ambonese district head. They were sentenced to clean up the roads around the district office.

One morning at 10:00 o'clock, when the district head went to supervise the convicts, he saw them sitting around smoking cigarettes. He got very angry and said: 'You bums, you know you're nothing more than wild boars routing in the ground for kasbi (cassava).' When he expressed his anger in those demeaning terms, two of the convicts ran over to the window I was sitting by and reported the insult of the district head.

Then I told them, 'Run quickly, back to the place where you are working so the district head won't see you over here.' I still remembered the words of the Ambonese in Hollandia-Binnen back then, which were so insulting and demeaning to Papuan dignity. So I waited until the district head had arrived back at the office and sat down in his chair, then I came right into his room, and said: 'Your deeds haven't disappeared with the blast of the H-bomb the Allies dropped in Hiroshima. Deeds that insult and demean Papuans still live!' Angrily, I struck him so hard that he fell down, along with the coconut-frond wall of the office.

Next morning, he went to Hollandia-Haven to the HPB's office to report me, and asked that I be immediately transferred from Sentani district. After the HPB heard his report and request, he telephoned me to come in the next morning myself to Hollandia-Haven to see him. Since it was an order from a superior, I hurried over there to make a formal appearance. There the HPB asked me to relate what had happened between me and the Sentani district head. After I had told him the whole story, the HPB said to me: 'Say, Trajanus, Mr. Thenu has asked for your immediate transfer, but I am the HPB for the Papuans, not for the Ambonese.'

After that the HPB ordered me to return to Sentani, saying: 'Trajanus, go back and keep on working; later I'll report this matter to the resident 
and it will be followed up by the directeur van binnenlandse zaken (director of home affairs).' I returned to Sentani and resumed work as usual together with the Ambonese. That same week he received a besluit strafoverplaatsing (a decree of penalty transfer) to Pioniersbivak on the Mamberamo river in the interior. I continued working in Sentani district, which governed 29 villages, namely, Ayapo, Puai, Asei Besar, Asei Kecil, Ifar Besar, Ifar Kecil, Siboiboi, Sere, Yobe, Yabuay, Ifar Babrongko, Puyoh Besar, Puyoh Kecil, Simporo Babrongko, Dondai, Kwadeware, Doyo, Sesiri, Yakonde, Sabron Samon, Sobeyap, Aib, Sokori, Dusai, Waibronbano, Waibronway, Maribu and Buyanggena.

\section{TRANFERRED TO DEPAPRE}

After three years' duty in Sentani district, in 1958 I was transferred to Depapre in the position of district head. While I was the Depapre district head, one time in 1959 I received an official letter from Hollandia, that Mr. Controleur Fanoy and Mr. Schoolopziener (Schools Inspector) Willem Inuri would be coming for a working visit to the Depapre district area. As district head, I made all the preparations for the departure with the group from Hollandia.

When the appointed time arrived, along came the group from Hollandia. Since I had prepared a boat equipped with an outboard motor, we set out from Depapre toward a village bordering on Tobati district, namely, Ormu Kecil. According to the plan, the work visit began with the easternmost village of the district and proceeded to the next villages until we ended up at the westernmost village bordering on Demta district.

On arrival in Ormu Kecil, we headed to the temporary camp set up in the village. Mr. Controleur Fanoy went straight into the kitchen. Because he could not see any water or firewood in the kitchen, he immediately became angry at the korano and ondoafi of the village, saying: 'Pigs, bastards, why have not you prepared all this?' But the korano said: 'Master, we have already taken care of it and it will soon be here.' I did not like hearing these humiliating words, so degrading and disrespectful toward the people of Papua, and I said to Mr. Controleur Fanoy: 'It is precisely because of the people of Papua that Mr. Dutchman came to Papua to develop Papuan people in need of development.' Then I hit 
and kicked him until he fell down. Mr. Schoolopziener Inuri watched me, then said: 'Had I known it would be like this, I would not have come to patrol together.' I said nothing, but sat quietly, feeling very annoyed. I felt sorry for Mr. Controleur, and immediately arranged with the village people for a boat to take him home to Hollandia by water.

In conducting this official trip, we went from village to village and finally we arrived at the last village, Kendate. Throughout the trip, Mr. Schoolopziener inspected schools, school children and teachers in all the villages. After the end of the working visit in the last village, we returned to the Depapre district post, and the entourage from Hollandia returned byland to Hollandia. In Hollandia, Mr. Controleur reported me to the HPB and the resident, and the report was forwarded to the Department of Home Affairs and the governor. Soon after that, the head of the department of information, Mr. Merkelijn, came to Depapre and informed me that I had been summoned by the governor of Hollandia, and so, he had come to pick me up. We immediately left Depapre for Hollandia byland.

When we arrived in Hollandia-Binnen, a reserve car from the governor was waiting for us, and we directly boarded the car to go to HollandiaHaven, and arrived at the governor's palace in Dok V. Controleur Fanoy and I appeared before His Excellency, the governor. There we shared our reports and related the incident that had taken place in Ormu Kecil. The governor, I, and the controleur each spoke. I proposed to Mr. Governor that since it was Mr. Controleur who had reported me, Mr. Controleur should speak first, then me. The controleur spoke, then the governor said that it was now Mr. Trajanus, the Depapre district head's turn. After being heard by the governor, and attended by the resident, the HPB and a representative of the Department of Home Affairs, the governor directly blamed the controleur and vindicated me. Then I shook hands with the controleur as a sign that the problem was resolved, and returned to my job in Depapre. The governor gave an order to the Department of Home Affairs for the controleur to be transferred and reassigned as the HPB in Boven Digul (Upper Digul).

After serving two years as district head in Depapre, I was transferred to Arso district to replace the district head who had left the post there some time ago. Arso district governed 16 villages, namely: Arso I, Arso II, Wor Kwana, Wamber, Wembi, Witi, Pegeur, Kwimi, Sawyatami, Singgwar, Nyaw, Kofo, Yamas, Sawa, Skotiafo and Skofro. In Arso dis- 
trict, as the district head I was also appointed by the director of transport and energy as the supervisor of the Arso airfield, which was built by the Catholic Mission and was actually owned by the Catholics. Then, because the Unurum district head had received a penalty transfer and left that district vacant for so long, in early 1961 I was transferred from Arso to Unurum to become district head there.

\section{A HUMAN FENCE ON THE RIVER}

Once everything was ready, we departed from Arso to Hollandia-Binnen (Abepura), travelling on foot for two days because it was the rainy season. I then came before Mr. HPB in Hollandia-Haven to let him know I was ready to leave Arso. Mr. HPB quickly made arrangements with KLM flight parties for me to return by a Twin Pioneer aircraft. Shortly after arriving in Arso, I re-boarded the Twin Pioneer plane with my family to return to Sentani airport. From there, riding by car, we went and stayed awhile in Hollandia-Binnen. After resting for four days, one morning we were transported to Yoka, at the east end of Lake Sentani, and continued, travelling by ferry boat to Borowai at the western end of the lake. At that time, the ferry was the only means of transportation between the Yoka and Borowai (see map).

In Borowai there were no inhabitants; only one Dutch family lived there. The family kept chickens. Because, when I first served in Sentani district, usually on my official trips or tours, I used to stop in Borowai, this Dutch family knew me, my family and I were given lodging at their house. The following morning at 07:00, my family and I and the porters walked to Genyem. Because the trip was with the family, it took two days.

On the way from Borowai, we stayed overnight in kampung Mamda Besar. The next morning we headed for Genyem and arrived there at 13:30 in the afternoon. After arriving in Genyem, the next day I came before the Nimboran HPB, Mr. Hilkemeijer, to report that I had arrived with my family in Genyem and would later head for Goeai, to take up my post in Unurum district, based on the besluit for my transfer from the DBBJ. Mr. Hilkemeijer invited me and my family to rest for one or two weeks before leaving for Goeai.

Two weeks later, one morning at exactly 09:00, we departed for Genyem on foot and arrived in kampung Nembontong and stayed over- 
night there because it was raining that day. The next day, at 07:00 in the morning, we left Nembontong for Buasom and arrived there at 16:00 hours. Halfway through the trip, we had to pass the Sarmaiwai river.

We tried to cross the river, but did not dare because the current was very swift; what is more, it had rained especially hard the night before. Finally, most of the 85 porters held hands, forming a single line like a fence, and my family and I, held by the other porters, began crossing the river. The fence managed to reduce the swiftness of the current so that I and my family could get across and arrive safely on the other side.

The next morning at 07:00 we set out from kampung Buasom. But because it was raining so hard, half way there, we were forced to overnight. The next day too, we stopped to spend the night in the middle of the trip again because the downpour was so heavy. The next morning, at 07:30 sharp, my family and I started walking again, following a plateau, then we climbed a mountain and came down on the other side of the mountain and continued the very tiring journey until at last we arrived safely at our destination, namely, the Unurum district post where my new job posting was.

\section{A VILLAGE FOREMAN'S WIFE IS TAKEN HOSTAGE}

After staying one month in the place, I made my first official trip to visit all the villages in Unurum district, which took three weeks since the district was very large. The distance between one village and another took a day or sometimes two days to travel. But I never felt hopeless or complained, because it was my duty as a civil servant, and also, it was my original intention to become a servant in service to my people, the nation of Papua. At one point in the year 1961, the police detachment commander in Genyem, Lieutenant I Lamertze, made an official trip to Goeai, bringing along a woman from the village of Jadam. I asked Mr. Lamertze, 'This woman - where is she from, and why is she travelling together with Mr. Commander and other members of the police?' Then Mr. Lamertze began telling me the story. He said that in Genyem he had heard reports that in kampung Jadam there was an old man who lived alone on a mountain since the end of World War II and had long kept a Japanese-made weapon. Because of that information, the police went on a patrol to Jadam. Because the old man's hiding place was so remote 
and hidden, he brought along as a guide a deputy of the korano of the village, who was also known as the foreman of kampung Jadam. When the patrol set out to climb the mountain to reach the place where the paitua lived, suddenly the village foreman fled. He was afraid of being shot by the old man.

The police commander got very angry. They returned to Jadam. To punish the village foreman who had run away, the police carried off the foreman's wife. Their plan was to bring the wife of the Jadam foreman to Genyem to hold her prisoner until her husband came to Genyem.

After hearing the story, I said, 'Mr. Lamertze, this is a grave mistake you have made. According to adat law and the customs in Papua, such things lead to great danger.' I gave the example of someone's dog, that if it were taken by someone in the same village, it would result in a murder, let alone a human being, and a woman who is somebody's wife!

'I am not afraid, I'm a policeman.' said Mr. Lamertze. 'Sir, I am a Papuan, and I know better than a police officer; it would be best for you and your patrol, Mr. Policeman, sir, to return to Genyem through kampung Jadam, and you must return this woman to her husband.' I tried to warn him. However, this Mr. Policeman felt he was a policeman; his patrol left Goeai following a different road back to Genyem, and the wife of the Jadam foreman continued to be detained in the police barracks.

A week after the departure of the police patrol from Goeai, I too left for Genyem.

I asked for help from the HPB to get Mr. Lamertze to immediately return the wife of the Kampung Jadam foreman. The HPB, as jurisdictional head of the Nimboran sub-division, summoned Mr. Lamertze and ordered him to return the man's wife right away. Thus, the woman was finally returned home to her village.

After the woman came back to her village, when, as is natural to a woman, her period came, the bleeding would not stop. The husband asked his wife, 'Hurry up you, confess, surely when you were in Genyem there was a man who slept with you.' As her husband continued to rage, clutching a machete in his hand, she was forced to reveal her secret.

Frightened, she admitted that when she was in the police barracks in Genyem, there were two policemen who had sexual intercourse with her. Upon hearing this, her husband became very angry and vowed: 'Starting today, I will eat no sago; only once I kill those policemen will I eat sago again'. From that time on, the husband waited and waited for the time 
when the police would come visit his village again. He waited for such a long time, but the police never did come to patrol that village.

THE BAD-OMEN HORNBILL

At the end of October 1961, I was called in to see the Genyem HPB, Mr. Hilkemeijer. Mr. Hilkemeijer said, 'Trajanus (usually, when Dutch gentlemen knew and were familiar with me and I with them, they used my first name), OK, take a rest for a couple of days first, and then take an official trip with me around the villages in your district, Tuan Bestir.' Two days later, together with Mr. Hilkemeijer, two police officers and all the porters carrying our retinue's goods, I left Genyem and arrived at the first village, Nembontong. Mr. Hilkemeijer told the village people, particularly the men, to attend a meeting. There, Mr. Hilkemeijer talked about cleanliness in the village. It seemed to me as if Mr. Hilkemeijer were holding an indigenous court session. When I heard the words filling Mr. Hilkemeijer's speech about the Ordonantie Ordekeur Molukken as well as the Ordekeur Molukken Rooiekeur Molukken of 1938, then I, as the district head, informed the HPB, Mr. Hilkemeijer, that regulations on maintaining cleanliness and beauty based on these 1938 ordinances could not yet be implemented here or in the interior. Because village people in the hinterlands did not yet know the regulations, and even the resident community in Hollandia-Binnen and Hollandia-Haven of people from Europe (the Netherlands), and the people from Indonesia and Papua who were already advanced, had not yet succeeded, since the city of Hollandia was still so dirty. But Mr. Hilkemeijer told me: 'Maar ik ben HPB, Tuan Bestir hanya ikut saya' (But I am the HPB, Mr. Administrator, and you just do as I say).

The next day, the whole delegation departed Nembontong and by the afternoon we arrived in kampung Buasom and spent the night. At that village too, a meeting was held with the villagers. The contents of Mr. Hilkemeijer's speech was the same as in the previous meeting in Nembontong. In the evening I called the korano of the village of Buasom and instructed him that the following morning at 05:00, the men carrying the goods for our group should leave ahead of time for a place that I specified, and there, set up camp to spend the night midjourney. 
We all woke up in the morning, and after breakfast, I, Mr. Hilkemeijer and the two policemen left Buasom, following after the porters who had left earlier that morning at 05:00. I felt sorry for Mr. Hilkemeijer, so I made sure the trip was not too tiring. During the trip I told the group to rest every half hour, then walk some more, and this applied throughout the journey; finally we met up with the group of porters who had gone ahead of us at around 16:00 that afternoon. The porters had set up camp. But because they had not continued walking to make the camp in the place I had specified, I got angry and tore down the camp they had made. I said to them: 'Last night I specified the overnight place, so why did you stop and make the camp here? Let's go, pick up the stuff and keep walking.'

Actually, I had specified the overnight place with the aim that the following morning, when we left again, we would arrive in Goeai at around 15:00 in the afternoon. The HPB's retinue kept walking, until we reached the place I specified at 18:00 that evening. There, the porters very quickly set up camp for me and the HPB, police and porters at the edge of a small river that was nearly dry. I told the two police agents to quickly boil some hot water, and after the water was boiled, Mr. Hilkemeijer and I mixed the hot water with Brinta porridge.

While Mr. Hilkemeijer and I were eating after six in the evening, a hornbill suddenly plunged down beside us. I was taken aback, because in all the years I had pursued my work as a civil servant, I had never experienced an event like this. Mr. Hilkemeijer looked at the hornbill that had fallen beside us, then said to all the porters that Mr. Administrator had to come and spend the night here in order to get this bird. Together with the two policemen, they cooked the fallen hornbill to be eaten, except that Mr. Hilkemeijer and I did not eat any. My thoughts grew heavy and I had an uncomfortable feeling. I sat down and told Mr. Hilkemeijer, that in the long time I had worked in the interior, never had a bird so suddenly come as close to me as this, let alone a hornbill, which is extremely wild and stays far away from humans, unless it is still young, that is, newly hatched, in which case can be caught and kept as a pet.

During the time I spent in Arso district, once, on an official journey, I heard a story from some villagers, that if you are walking and a hornbill falls alongside you, it is an omen of danger: later, the person leading the trip would have a death experience. I recounted this story to Mr. Hilkemeijer and the two policemen and the porters. I asked the porters 
if people in these parts also held a similar belief. They did not answer my question, indeed they remained silent. But Mr. Hilkemeijer told me that the fallen bird was a blessing for the evening meal, since we had travelled on foot until it was almost nightfall, so there was no time left for us to hunt there.

The all-day journey had been exhausting, especially for Mr. Hilkemeijer who had only recently been posted in Genyem and was visiting the villages here for the first time. Feeling sorry that he was so tired, I and Mr. Hilkemeijer went to sleep on a makeshift wooden bed covered with saplings, while the two policemen used the small shelter a bit farther off from us as they had to keep guarding Mr. Hilkemeijer and the HPB's working visit group.

The following morning, at precisely 07:00, we left the overnight place and then headed from there toward the Unurum district post, namely, Goeai. At 15:00 that afternoon we arrived in Goeai. Somewhere over half a kilometre later the headmaster of the elementary school of the Protestant Church in Goeai was ready and waiting with all his students to receive the HPB visiting Goeai. They welcomed the HPB with the Wilhelmus van Nassau, the Dutch national anthem, then the headmaster and schoolchildren led the HPB's delegation along the road towards the residence of the Unurum district head, blowing on flutes. In the evening, the same thing was done as in the other villages, that is, to gather the residents of kampung Goeai to listen to the briefing of the Nimboran HPB.

\section{MR. HPB IS MURDERED}

After Mr. Hilkemeijer had eaten supper with me and my wife, I invited him to go directly to sleep because he was so tired. Next morning, Sunday, Mr. Hilkemeijer joined the church service. Once all the members of the congregation had filled the church building, Mr. Hilkemeijer and I entered through the front door of the church. I knew that Mr. Hilkemeijer, during his time in Genyem, never neglected to join the daily church services.

Monday morning after breakfast, Mr. Hilkemeijer said: 'Tuan Bestir of Goeai, there's no point for you to come with me. Mr. Administrator, stay in Goeai to organize and ask the people of Goeai to provide land and places for the newcomers from the Mamberamo-Atas (Upper Mambero) 
river, so that the Mamberamo people can stay and build themselves shelters here. You stay in Goeai, and I will continue the journey with the group and return to Genyem myself. I want to take a shortcut so that later, you can follow the shorter road I take now.'

Being his subordinate, I followed his orders. Next, I instructed the office attendant to accompany Mr. Hilkemeijer's group to the villages in Unurum district, and told him that he should go with the HPB as far as Genyem and only after that could he return to Goeai. The HPB's group left for Dore. Two days later, at 17:00 in the afternoon, my wife suddenly started crying, screaming and calling out to me, and saying: 'Quick, come to the front and look, Office Attendant Alexander has gone crazy'. My wife said he was crazy, because she saw Alexander Maware tying a red handkerchief around his head, meaning that a murder had taken place.

At the time I was in the middle of repairing our bathroom. I immediately ran to the front of the house. And it was true, Alexander Maware had tied a lengso (handkerchief) around his head, and the colour of that lengso was red. I went back to the room and grabbed a Biak machete and moved forward, grabbing hold of the office attendant. In a very loud voice I shouted, lifting up the machete: 'Hey, Alexander, why do you look this way? Come on now, tell me exactly what's happened!' Alexander broke into tears, but I forced him in a loud voice: 'Come on, don't cry, tell me what happened.'

He said that Mr. Hilkemeijer and the two policemen had been murdered by people from kampung Jadam, and he had fled into the forest for two days and just now arrived in Goeai. I did not take this well, and I pulled Alexander Maware and was about to cut open his head when my wife ran over and put her arms around me, crying, 'Ooh, don't, don't cut him, so he can tell us how the murder came to pass.'

But I was angry and said to Alexander: 'If, the day before yesterday the HPB had not forbidden me to go along on the trip, then I should have died before the HPB died; I would have laid Mr. HPB's body to rest with my own, then we'd both die. This is our custom in Biak. Before I died, I would have put my own life on the line. What is more, you are from here, why did you not speak in the local language to those who wanted to kill the HPB and the police?'

I forced Alexander to sit down and tell the story from the beginning until the murder happened. He said that in kampung Jadam, the HPB 
noticed that there were houses with sago-frond roofs that were badly broken down. Then the HPB coercively ordered the village people, one by one with his machete, to climb up to the ridges of the houses to dismantle the roofs, and take off and dispose of them all. After that, the people came down from the housetops, machetes in hand, and directly killed Mr. HPB. The two policemen weren't disturbed, because one of them came from Genyem, and people in Jadam are usually afraid of Genyem people. But because the Jadam people were afraid that later the two policemen would shoot them, they killed the two police officers too.

Because I was feeling sad and upset, I remained furious with the office attendant, saying to him: 'If you heard what they were saying in the local language and knew their plans, why didn't you stop the HPB's group from spending the night there, so you could continue the journey to the next village?'

My wife sent for the teacher, to ask the teacher and the Goeai Congregational Council to gather at our house that night together with my family to hold a church service. We prayed for the delivery of the three victims who had been forced to abandon their families, in the hopes that Mr. Ir. Hilkemeijer and Police Officers Kapim and Nof would be received by God the Almighty. And that the families left behind would be granted fortitude.

Within a few days of hearing that awful and saddening news, I remembered Mr. Hilkemeijer's message: 'I will now take a shortcut so that Tuan Bestir Goeai can later follow.' In human terms, I personally understood and appreciated that perhaps what the HPB meant was that he was going to take a shortcut through life, and that I too would also take this short road, or die, just like HPB Mr. Ir. Hilkemeijer.

In the week following that shocking event, every day we heard the sound of an airplane circling around above the village where the murder had happened. One night, I heard the sound of human voices beneath the house where we lived; our house was built on stilts. I immediately fetched a flashlight and went out to take a look. My wife forbade me, saying: 'Don't go outside! Don't let it get to the point that the discontented villagers come to kill us too'. I said that the people of Goeai, who were the most feared here, would not necessarily let us be killed, that they would even protect us. 


\section{PROTECTED BY THE KAURE PEOPLE}

When I asked, those beneath answered: 'We of kampung Kaure have come to Goeai to stand together with the Goeai people, to protect and look after Tuan Bestir and your family'. Hearing that, I went inside and got some Shag 'Warning'3 tobacco and gave it to them. My wife too got up and made coffee for the people who were beneath the house.

Next morning, the village korano and ondoafi came over and suggested they bring me and my family home to Genyem through an alternate route that the Jadam people would not see. But I did not agree to the route they recommended. I asked them to bring me and my family down to the beach, precisely at kampung Kaftiauw, the last village of Sarmi sub-division, which bordered kampung Tarfia in the territory of Hollandia subdivision.

My wife called the teacher, and the village leaders of Goeai and informed them of our plan to return to Genyem, leaving them all behind. Then my wife said: 'I am handing over all the contents of this house, from the front back to the kitchen, the household furnishings, all of the tools and the utensils in the kitchen and the clothing in the closet, all of the contents of the house so they will be well taken care of. I ask for all of these goods to be divided equally among all the people in Goeai, because we are only going to bring the minimum necessary clothing as provisions for the journey'. The village teacher, korano and ondoafi accepted this, filled with sadness, and wept.

The next day, we - my family and I - were led out of Goeai on foot in the direction of kampung Kaftiauw, which was located on the beach. The journey took two days. In Kaftiauw my family and I were detained for the night. The next day we headed to Tarfia along the beach and spent the night on the banks of the Sarmaiwai river because it was already getting dark. We could not cross the river because the current was strong, not to mention the many crocodiles. We spent the night by a sandy bay, but could not sleep because of the torrential rainfall. We could not make a shelter in a clearing because it was already quite dark. I felt very sad as it rained all night long.

The next day, very early in the morning, we began walking again following the coast, and in the afternoon arrived in kampung Tarfia. The

\footnotetext{
3 Shag brand tobacco had a warning printed on the package. Instead of the brand name, Warning was taken to be the name of the tobacco.
} 
residents of Tarfia asked us to stay because they saw that my wife and children were in a very tired state. I had visited this village before, when I was the district head in Depapre. The next morning we were brought by boat to Demta, the capital of Demta district, and spent the night there. And the next morning, after climbing up and down a mountain, we reached and stayed the night in the village of Berap. The following morning we went on foot to Warombaim. After a brief rest, we resumed the journey and arrived in Genyem at 13:00 that afternoon.

\section{THE HUNT FOR THE HPB'S MURDERERS}

The new HPB to replace Mr. Hilkemeijer was Mr. de Jong. When I went before Mr. de Jong, he conveyed to me that I should stay in Genyem to wait for a decree from the Department of the Interior (DBZ). I heard that during the month of November 1961, the Dutch police and army troops had entered Jadam to find the ones who had committed the murder of HPB Ir. Hilkemeijer and the two police officers. All of the inhabitants of the villages adjacent to Jadam had fled into the forest. Some of the elderly people, who did not have the strength to escape and had stayed in the villages, were shot dead.

When I heard the news, I left for Hollandia to see the resident and lodge an objection. The resident immediately telephoned and summoned the afdelings commandant politie (ACAP, divisional police commander) of Hollandia and discussed it. I asked that the resident and the ACAP immediately withdraw their forces from the villages around the place where the incident took place. And that I myself would go in to look for the perpetrators of the murder.

Both the resident and the ACAP asked who would be responsible if I too were murdered. 'If they kill me, what can be done? What is important is not to turn village people who know nothing about the matter of the murder into shooting targets', I said. In late December 1961 I prepared for departure and invited along a former district head of Goeai, namely, Mr. Dimara. We brought one crate of Shag tobacco, sugar, coffee, tea, salt, matches, candles, syrup, rice, bath soap and laundry soap, with the intention that if we succeeded in finding them, we could celebrate Christmas and New Year's together. We arrived at the bank of a river and spent the night there. 
There we met a family who was fishing. I called them over to stay with us in the shelter we had constructed with a roof of leaf mats. Then I asked: 'Do you know the Jadam people who murdered Mr. HPB and the two policemen? Do you know where their hiding place is? And can you contact them?' The villagers, afraid and hesitant, let me know where those people were hiding. Finally, they promised they would contact those who were hiding in the woods. I instructed Dimara to prepare enough Shag 'Warning', salt, matches, then the people went into the forest to find them.

One day later, the person appointed as the courier came back to our post and let us know they had met with the Jadam people and handed over the things I had sent. The next day, I told him to go back into the forest and deliver my message that, if they were willing, we could agree on a time and place to meet. After another day, the courier came. He said that the Jadam people who had murdered Mr. HPB knew me and Mr. Dimara. They had said: 'Biak people are good people'. A time and place to meet had also been agreed, that is, Sunday at 13:00 in the afternoon in kampung Jadam.

On Sunday morning, we held morning prayers, even though it was in an inappropriate place on the bank of a river in the middle of the forest. I led a short service. The ones who led the way for me and Dimara to Jadam were just the women. The men did not come along because if the killers saw men, they would get angry because they would suppose they wanted to take revenge. We travelled on foot along the river and finally climbed a mountain, and soon arrived at the top of the mountain where the villages of Jadam and Tambang were located.

At exactly 12:00 noon I arrived at the place, but they had not yet come down. Because I was so tired from climbing the mountain, I said to Dimara: 'Let's both sit on the mountain peak, and all the women go inside the empty houses and pray'. Earlier, when we were heading toward the agreed upon place, I instructed a woman to wrap my hunting rifle in an areca leaf frond so it could not be seen, while I placed my pistol into my right pocket, then made a hole in my trouser pocket and tied the pistol to a bit of string that passed through my underwear and wrapped around my neck, so the pistol was not visible to anyone from the outside.

Sitting on the mountain peak so that I could see far all around, it was not long before I heard a sound like that of someone falling and the sound of a bow and arrow. I slowly scrutinized the slopes of the moun- 
tain and saw that someone was climbing the mountain below where Dimara and I were sitting. I immediately stood up and called down to him: 'Come on, you, come up quickly. Why are you peeping on the two of us?' The man's name was Piliphus.

I asked Piliphus why the others had not come yet. He said they were under a big tree. Then he went to call them. To receive them, I told Dimara to stand around ten meters away from me, and I said to him: 'Later when they come out to greet us, if I get hit by an arrow or spear, Dimara, you must not wait, but dive into the gorge and run as hard as you can. Leave me here, because you have eight children, Dimara, and run for safety. I'll stay here, as I only have four children.' Dimara listened to my orders, his body trembling.

Soon after that the moment we had been awaiting arrived. The killers emerged and came toward the place where I was standing. They readied themselves, some raising their spears, others fitting arrows into their bows, as they stepped slowly toward me. It was not long before a voice from among them could be heard, saying: 'Dawem (which means 'hello' or 'good afternoon') Tuan Bestir Boekorsjom.'

I hailed them and said: 'Stop there, do not walk any closer, because I am afraid of you'. From their midst came the words: 'Bukan babi piara supaya bunuh dua kali' (A pig is not raised to be slaughtered twice). Then the korano of Jadam, who was holding a bow and arrow, said to me: 'We already know those who come from Genyem. Ever since you started out from Genyem we have known that the ones coming were Mr. Boekorsjom and Mr. Dimara. You two are our fathers. And we already know that you have not brought the police or the military - that is why we have come down and want to meet.'

Yet they maintained a warlike stance and lined up in front of me. I asked them, was it true they wanted to surrender? They replied through the ondoafi: 'We really are surrendering today'. I then said: 'If you really want to surrender, let us prove it, that is to say, I'll move forward in front of you and the ondoafi will also come forward to stand beside me, and you will surrender all your bows and arrows to me as proof that you really want to surrender to me'. They replied through the leader that they really wanted to surrender that day.

I repeated the same words: 'If you really want to surrender, let us prove it, that is, I'll move forward in front of you and the ondoafi will also come forward to stand beside me, and surrender all the bows and ar- 
rows to me while we shake hands'. And when Dimara stepped forward, the korano too stepped forward, and the korano handed all the bows and arrows to Dimara, then the two of them shook hands. The moment everyone shook hands, the automatic camera I had put on top of a heap of coconut shells immediately took photos, and so the handshaking event was complete. What a pity it is that later when Indonesia came in, I had to move house in a hurry, and those photos were all lost.

\section{MEETING THE HPB'S MURDERER}

I told them all - more or less 30 people altogether - to go into the house of the Gospel teacher that had been abandoned when the murder took place. Inside the small house, there was still a dining table. I told them to sit on the floor of the house, and only I, Dimara and the korano along with the ondoafi sat by the table. Since the ceiling of the house was low, they placed all their weapons (spears, bows, and arrows) in the ceiling rafters above our heads. Then they sat down on the floor, each sitting on top of his machete, around me and Dimara. I told Dimara to take out the Shag Warningtobacco and matches and distribute these to everyone.

While smoking the tobacco, I gave a message to Dimara in the Biak language, which the people of Jadam could not really understand. I instructed Dimara that if there were any signs of danger, when I stood up, Dimara should jump out of the house as fast as he could and wait down below. I would kick the table so that the korano and ondoafi would fall with the table and then I would seize both of their machetes and throw one to Dimara and hold onto one myself, and both of us would take action, because the machetes were Biak machetes and we would fight. In this case I was brave because they would only have machetes, while their spears, bows, and arrows were in the ceiling of the house. I also had experience and knowledge of how to use a machete, because I had followed training in fencing when I attended courses at the police school for 13 months.

After giving my instructions in the Biak language, I began to ask them why they had killed Mr. HPB and the two police agents. They replied: 'Actually our plan was not to kill Mr. HPB, but to kill the police commander of Genyem, but although we waited a very long time, police never came. As it happened, Mr. HPB came to the village, then the village foreman, whose wife who had been taken by the police and detained in 
Genyem, said: "The sago is ripe, let us eat; do not wait anymore". Upon the foreman's words, then we moved and committed murder against Mr. HPB and the two policemen.'

I asked who it was who had killed the HPB. They replied honestly, pointing to the perpetrators. 'This is the person who held down the HPB, and the one who killed the HPB is this one. Meanwhile it was these two people who held down the two policemen, and these two who killed the two policemen.'

After advising them, I made an agreement with them: 'On Friday, five days from now, we will gather in Unurum; since I've brought candles, syrup, and tobacco, as well as many other things, we can celebrate the Christmas feast and the 1962 New Year together at the same time. You all will look for vegetables, pork, cassowary meat and kangaroo meat and sweet potatoes and yams, and I will bring rice, canned fish, and corned beef. So, on Friday afternoon we'll meet up at kampung Unurum. My group and I will come from the river and climb to Unurum. And you will come down and meet me there with the food supplies, so we can hold a service to celebrate Christmas and New Year.' Then I sent them back to their hideout in the forest.

Dimara and I, with the women leading us, went down the mountain and arrived at our post at 17:30 that afternoon. Upon arriving I saw that the men of Goeai and Mamberamo-Atas were already at their temporary post. With a loud voice they courageously said: 'Sir, you need not fear anymore. We are here, only if we die will Mr. Dimara and Mr. Boekorsjom die.' In keeping with the joint agreement, on Friday morning we and the whole group from Goeai set off, following the river toward kampung Unurum. We walked on foot, not going across the lowlands, but continuing to climb the mountain, and at 11:00 o'clock we arrived at Unurum. After arriving there, I told the Mamberamo and Goeai people to collect wood and thatch (sago) leaves, using their ribs for roofing, and we set up a sort of provisional shelter that could accommodate up to a hundred people.

Because I was too tired, I climbed into the village hut to rest, and fell asleep. I was not aware of the Goeai and Mamberamo setting up the makeshift shelter. On completing the building, they walked up to kampung Doetasen while I slept alone in the hut. Suddenly, I was startled by someone coming out of the woods and climbing into the hut. The person 
who came was the same one who had tumbled with his bow and arrow when Dimara and I were sitting on the mountaintop in Jadam.

The man whispered: 'I want to let you know, Tuan Bestir. Under the tree there is a gang of men from kampung Bebotehe. They are planning that tomorrow afternoon when everyone is in the prayer house, they will come in suddenly and a man called so-and-so will hold down Tuan Bestir and the one who will stab or kill Tuan Bestir is a man called so-and-so. Meanwhile, the one who will hold Dimara is a man called so-and-so, and the one who will stab or kill Dimara is a man called so-and-so.'

Why did those villagers want to kill me and Dimara? The man told me that the villagers were very angry at the Jadam people. Because the Jadam people had murdered Mr. HPB and the two policemen, the residents of the other villages were afraid and fled to the forest, and now their wives and children were dead. So they wanted kill us so that the Jadam people would also flee into the forest and their wives or children too would die there. The man then returned to the forest.

\section{FLEEING TO THE FOREST}

At exactly 17:00 that afternoon I beat the breng-breng or tong-tong (gong) hanging in the hut as a signal to call and gather people in front of the hut. At the sound of the gong, my group ran down from the village on the mountain, and assembled along with some people from the villages of Unurum and Doetasen in front of the hut. Immediately, I gave orders to the people, that the next afternoon at 13:00 we would hold the Christmas and New Year's service. And for that, I instructed them, the next day, from morning until almost afternoon, everyone should go into the woods looking for vegetables, pigs, and so on, so that by 12:00 noon all could reassemble again back here, to celebrate the Tree of Light and the New Year.

Further, I said that the next morning at 06:00 I would not see anyone wandering around in the village; everyone would already have gone into the forest to hunt and look for food in the gardens. Dimara and our group were also standing in front of the hut and they assumed that my instructions were genuine. They knew nothing about what I had just learned. In the evening at 19:00 hours we were all inside the hut. I had not yet told them whether my earlier instructions were true or not. I told 
them to hurry up with the cooking and eating. I called Dimara over, then in whispers told him that there was a plan to kill us both. The orders I had given before were just a trick, so that the next day nobody would be in the village, the whole village would be deserted. And we would run out as quickly as possible and leave the village before noon. So Dimara finally learned that my orders were only to fool them, so the village would be empty.

As we chatted, Dimara and I roughly calculated how many men lived in the surrounding villages, so that if we had enough bullets, I wanted to wait for them to come to fight. I gave him a long-barrelled gun with 700 bullets, while I myself used a .38 calibre Colt ladies' pistol. I instructed Dimara: 'If they come to attack us tomorrow afternoon, Dimara, you must not shoot when they are still far away, because then our bullets will run out. You should wait until somebody comes close with his spear, and only then fire any bullets. I'll use the two pistols I have with me. If we run out of bullets, we'll throw away the guns and take up machetes. We'll appear with machetes there. And if they come at us doing adat dances and wearing cassowary feathers on their heads, then Dimara might get dizzy and fall. Under those circumstances, Dimara, stand behind me, and I'll deal with them myself.'

I saw that Dimara was not keen and sitting in silence. 'Dimara, would you like us to run or wait for the enemy from the villages?' 'Tuan Bestir, my younger brother, you are the one leading this expedition and my boss; if Tuan Bestir, my younger brother says we wait, yeah, then we'll wait. If you say we run, yeah, we'll just run', Dimara replied.

Then I made the decision that the next day, really early in the morning, before 6:00, we would all come down from the camp and run away from the village. After I spoke with Dimara, I informed the group that the next day very early we would have to run away from that place. So they all would know that my orders earlier that afternoon were not true; I was only tricking them so they would go into the forest, and we would have a chance to flee from there because there was a plan to kill me and Dimara. Because it was dark under the house, I used sign language, instructing them as follows: 'Tomorrow, just before dawn, all of you will wake up and make sago pancake (sinole). You'll open a tin of margarine to butter the sinole and eat. You'll make coffee with Pelco (powdered milk). After that, everyone will put on your eating tins while you are sitting down, so everything will be truly ready for us to get up all at once to 
move quickly down the ladder and run out of the village. We'll run and run until the place where I say to sit down, only then can we sit down to rest, with the eating tins still hanging from our shoulders.'

All the preparations were made by 03:00, in the middle of the night. No one could sleep because of the dangerous situation. We quickly descended from the house and began moving, leaving the village behind, still in a state of silence. Upon reaching the edge of the village I saw the ondoafi of kampung Unurum, who stayed there alone because he was so elderly he could not walk very far. I went in and shook hands with him and said good morning and goodbye. The whole group had already run far, but because they did not see me, two people ran back and firmly said to me: 'Come on, hurry up, do not stay long! Tuan Bestir, it was you who ordered us to run, why are you still moving so slowly?' All along the way, the route we went through was surrounded by jungle, so the Mamberamo people went more than 20 metres in from either side of the road. They ran and scouted the forest to make sure people weren't chasing us.

We ran until 11:00, then I told them to rest for ten minutes. After that we all got up and continued the journey, overwhelmed by feelings of caution and vigilance. Upon reaching a high mountain peak, I instructed them to rest and take out the sago sinole and margarine and sweetened milk for lunch. After that we kept running, up and down the mountain. From the mountaintop, while we were resting, someone came running from kampung Unurum. 'It is lucky that Tuan Bestir and your group fled from that village. If you had stayed, there would have been a big war, killing more people. The villagers (of Bebotehe) were very frustrated to find the village (Unurum) empty,' he said.

On that very day, the Indonesian warship, Macan Tutul (Leopard) was sunk by a Dutch warship. The following morning we did not go by the usual route to Genyem, but headed down to the beach and spent the night there. The next morning the entire group went on foot and arrived in Genyem at 15:00 that afternoon. The people in Genyem, who had been waiting for news of our trip, asked about our situation. They could not understand why we had not come back to Genyem through the usual route, but following an indirect path. It meant there was something going on.

I received a letter from the DBZ for me to get ready to be transferred from Hollandia to Biak. But I went before him and told him that I did 
not agree to be transferred to Biak yet. I wanted to stay on in Hollandia until the Jadam people who killed Mr. HPB were processed at court. But the police detachment commander in Genyem, Lieutenant I Lamertze, also must be dragged into court.

Because I objected to being transferred to Biak, my boss appointed me district head in Genyem. I always remembered, from the time I studied at the OSIBA, that my job was to take care of the people. Genyem district oversaw 14 villages, namely: Genyem Besar, Genyem Kecil, Sanggai, Benyom, Ombrop, Nembontong, Warombaim, Pobaim, Sarmai Down, Sarmai Top, Imene, Imsetum and Kaitemong. From 19 November 1961 until the end of August 1962, the government did not deal with the problem of the murder of Mr. HPB's and the two policemen. The military and police here were giving priority to security and the protection of Nieuw-Guinea from the planned attack of the Tri Komando Rakyat (Trikora, People's Triple Command) under President Soekarno's command to seize West Papua from the Dutch.

\section{HAVING TO MASTER THE LANGUAGE}

As a civil servant I prioritized service to the community, as I had been taught through the education I received at the School for Indigenous Administrators in Hollandia-Binnen. In practice, I did not feel like a master, but felt I was a servant of the people. Whenever I was deployed in a new place (district), I was determined to learn the local language. Because when you have mastered the local language, it is easy to learn the customs of the community. Mastering the language and adat was like entering a house in the dark. I had to find where the power outlet was and immediately turn on the light so the house brightened up. Language and adat are tools for making contact.

Once I became familiar with the customs, I could succeed in my work, because my actions would not clash with the culture and adat of the community. Once I knew the culture and adat of the community, in performing my job, I had to be careful not to violate the adat. Because if what I did was not in accord with the ways of life and habits of the community, they would think Tuan Bestir was transgressing their adat. As a result, the people would see me as a vandal. And even more fatal, 
the people would increasingly distance themselves from the government as time went by.

Since I mastered the language and adat, I was able to win their trust. I could carry out any order from the government as a civil servant and serve as a spearhead in the remote areas where I was assigned. An HPB did not make the development plans in the villages, because he did not know the situation of the village.

At the same time, the buildings used as district offices were not constructed according to the plans of our superiors. For example, the Arso district office was just an ordinary building, the same as a village home. The roof was very low and covered with sago leaves, the poles were made of fruitwood, and the shelves for books and office files were made of sections of bamboo. The work benches were made of pieces of areca wood, and the office walls were covered with sago leaf ribs. How could the HPB make plans, if he did not see with his own eyes the local situations or district offices in the interior, all the more so in villages that were still in the middle of the forest?

One day, the resident of Hollandia, Mr. Eibrink Jansen, and the HPB of Hollandia made plans to visit Arso to see the condition of the district office, because in the monthly report I had reported on the conditions of the office, and the homes of the district head and clerk, as well as the home of the office attendant. When the resident of Hollandia arrived at the Arso airfield, I welcomed them with a speech. I said that Arso district formed a small part of the contents of a book by Mr. van Eechoud entitled: Vergeten aarde (Forgotten earth).

The resident and the HPB wanted to see the office and home of the Arso district head. I said that the gentlemen could not enter the office because the office was too low for a tall Dutchman, so they could only see it from the outside. The same was true of the home of the district head, because that small hut was low and had no good place to sit. A week following the return of the resident and the Hollandia HPB to Hollandia, I received a letter from the resident that a budget had been prepared for building a district office, and houses for the district head, clerk, and office attendant, and that the physical construction would be carried out.

During the time I worked in the district, there were never any plans from my superiors. In each monthly report, official travel report, and annual report, I emphasized problems of health and problems of educa- 
tion, as well as the economic livelihoods of the small communities in the villages that did not yet have the capacity to promote human dignity.

One day, I left the Arso post, travelling on foot to the Waris district post, then the Waris district head and I walked together to the post of the Keerom HPB in Oebroep, which bordered the Baliem Valley, to see the Keerom HPB, Mr. Lind. After two days in Oebroep, the Waris district head returned to Waris, while Mr. HPB Keerom made a plan to visit some of the more remote villages in Arso district. I went on foot together with the HPB, a policeman and a paramedic toward kampung Sawa. The journey took three days. From there we went to kampung Yamas, then the HPB's group spent the night in kampung Kofo, and next morning headed on to kampung Niauw.

The trip was extremely long and led us through the mountains, and across rivers and plains where the heat was tremendous when the sun shone. We walked and walked, up to an area where conditions were terrible because the trail hugged the flanks of the mountain. There were no pathways to go up because the river was lined with mountains with steep inclines and we could not go down following the river because the mud was too thick and soggy, so we just followed the mountainside. We walked with our bodies tilted.

In one place there was a dry tree trunk, uprooted and overhanging the river. Mr. HPB, afraid of falling, took hold of a branch of the dried out trunk. Suddenly, the dry branch broke off and Mr. HPB fell. Mr. HPB got angry and said: 'Godverdomme, dat stinkende Papoea' (Goddamned stinking Papua). As a Papuan I did not take well to Mr. HPB's remark. Afterwards I approached him and said: 'Hey, say that again, if you're a man'. Yet in my heart I pitied Mr. HPB and I helped him get up and we sat askew on the slope of the mountain. I told our group to rest for about half an hour. Mr. HPB was fat, so he perspired a lot throughout the journey. Mr. HPB had run out of water, and I took out my veldfles (water canteen) and handed it to him to drink. I still had another one in my rucksack. I resisted my thirst for water so the water could be kept for Mr. HPB. Because it was already 17:00 in the afternoon, I instructed some porters to run ahead to ask the korano of Niauw for the villagers to come, and bring kerosene lamps to welcome us. The Niauw people came running to greet us, and with the lamps they brought we walked slowly along, and by 20:00 hours we arrived in kampung Niauw. 
Indeed I was angry with Mr. HPB, but how I pitied him. He had proven himself as a bapak rakyat (father of the people). He was willing to walk on foot in the midst of dense jungle. That amazed me. In the following days we kept walking until finally we reached Hollandia-Binnen. As a civil servant, moreover, a district head, I did not have the capacity to develop society. I just endeavoured to ensure that the people could gradually come to live healthy lives, to have enough food and get an education to sharpen their minds.

When I came to villages where the food consisted of edible tubers like taro, yams, and cassava, I urged every family to have a garden, so they could have enough food. For their children to be physically and mentally healthy so they could go to school. I encouraged the villagers so they would slowly come to understand how important school was for their children. If their children always went to school, then their lives in the future would be better than their parents' were now.

When I came to villages where the food consisted only of sago, I invited and directed and urged them not to eat only sago. If there was forest with dry and fertile soil, it would be better to make gardens and plant tubers and vegetables, so they could eat these as well. In my opinion, sago contains very little calcium, and it is desirable to eat lots of tubers and vegetables, because this is crucial to children's growth.

\section{TAXES AND HEALTH}

Regarding belasting (taxes), I carried out tax collection in the districts on the coast and in the districts near the city. But when I became a district head in the interior, I did not do any tax collecting, because people in the interior were not able yet to pay taxes. They did not have taxable livelihoods. But there were some who did earn a living, although their income levels were still very low. For example, the coastal people who gardened, with garden crops, those who were fishers, with products from the sea, those who worked as construction labourers in the cities, with daily wages, and those who owned a means of transportation (motor boat) - they could be taxed a little each year.

The diseases people generally suffered from in those days were malaria, tuberculosis, leprosy, and filariasis (elephantiasis). At that time, the greatest enemy was malaria, which was considered a deadly severe 
disease. After the health parties established an agency for the eradication of malaria or malariabestrijding, there was visible progress in eradicating this number one disease. I watched officers from the World Health Organization (WHO) from Manila joining in to help out. At the time I was the Arso District Head, a WHO inspector called Dr. Paul came and wanted to visit the villages. I took him to the villages of Wor and Kwana. After surveying the conditions of the people's houses, we crossed the Tami River, and then headed on foot to kampung Wambes.

The WHO inspector from Manila was fat. He got very exhausted passing through the swampy path. He rested every time he walked for about 10 minutes. Accompanying him, I finally got left far behind the main group. But the WHO inspector was very happy to be entertained by the sounds of an assortment of birds, especially the bird of paradise. The delegation later headed to kampung Wembi, although the WHO inspector could not continue the journey. He returned to Arso and went on to Hollandia.

In the Dutch era, the Health Department truly dealt with the eradication of diseases in Papua. Each type of disease was handled directly by a doctor, so the designation came first: malaria doctor, tuberculosis doctor, yaws doctor, leprosy doctor. The doctors who handled the various types of diseases did not stay quietly in the capital of Hollandia, but made visits to the villages for months.

In each district where I was on duty as a civil servant, a paramedic was also placed. When I made official trips to the villages, the paramedic also came along. In every village I visited in doing my duties as a civil servant, the paramedic opened a polyclinic in keeping with his duties in the area of health, and this way of working applied on every official trip. 